\title{
AZ ÁLLATOK MEGJELENÉSE A FÖLDRAJZTUDOMÁNYBAN: AZ ÁLLATFÖLDRAJZI RÉGIÓKTÓL A GEOGRÁFIA ÉS AZ ANIMAL STUDIES KAPCSOLATÁIG
}

\author{
VARGA GYÖRGY \\ ANIMALS IN GEOGRAPHY: FROM ZOOGEOGRAPHIC REGIONS TO THE \\ RELATIONSHIP BETWEEN GEOGRAPHY AND ANIMAL STUDIES
}

\begin{abstract}
This paper investigates how animals have appeared in geographical works from the discipline's institutionalisation until recently. I scrutinize the different animal geographies in broader context to shed light on the motivations behind why geographers focused on animals from different perspectives. This overview is especially important for evaluating the novelty of the 'new' animal geography. The distribution of animals on Earth has been investigated in many 'geographical' works since the 18th century but most of them were not written by 'geographers', even after the institutionalisation of the discipline. The geography of domestication and domesticated animals also has a long history, but the Berkeley School, whose representatives were especially active in this field, was pushed into the background in the second part of the 20th century. The 'new' animal geography that focused on the human-animal relation started to unfold in the 1990s.
\end{abstract}

Keywords: animal geography, Animal Studies, domestication

\section{Bevezetés}

A földrajzi gondolat története címú munkájában TELEKI PÁL azt írta, hogy a „,öldrajzi tudomány elsősorban mindenkor az volt, amit annak tartottak" (TELEKI P. 1917, p. 9.), ami rávilágít a geográfia sokrétűségére. Ugyanakkor a diszciplína tárgykörét vizsgáló különböző tanulmányokban (pl. VILES, H. 2005; CASTREE, N. 2011) az ember és az ôt körülvevő környezet, illetve a társadalom és a természet kapcsolatát hagyományosan a földrajztudomány (egyik) fó fókuszterületeként azonosítják. Ennek fényében meglepő, hogy az ember-állat kapcsolattal foglalkozó földrajztudományi munkák száma - főként az 1990-es évekig - viszonylag csekély volt.

Az állatok a nemzetközi földrajzi szakirodalomban a 20. század közepéig döntően természettudományi közelítésú munkákban jelentek meg, az állatföldrajz a biogeográfia részét képezte. Az állatföldrajz ilyen módon történő értelmezése hazánkban is jól ismert és napjainkig szinte kizárólagos, mint azt a Magyarország Nemzeti Atlaszának 2018-as kiadásában szerepló állatföldrajzi fejezet (VARGA Z. 2018) is igazolja. Főként az angolszász világban azonban - leginkább az 1950-es évektől kezdődően - a háziasítással, illetve a háziállatokkal kulturális földrajzi közelítésben is foglalkoztak. A század végétól pedig - párhuzamosan a más tudományterületeken, illetve a tudományos szférán kívül zajló folyamatokkal - az ember-állat kapcsolatra összpontosítva a földrajztudományban is többféle új irányzat mentén kezdtek foglalkozni. Az állatföldrajz tárgyköre tehát jelentôsen kibővült. Ugyanakkor a diszciplína „reneszánsza” elsősorban a „nyugati” világban tapasztalható, hazánkban mindeddig kevéssé éreztette a hatását.

Jelen tanulmányomban ezért amellett, hogy áttekintem a szúkebben, a biogeográfia keretei között értelmezett állatföldrajz történetét (fóként a 18. és 20. század közötti időszakra fókuszálva), olyan további irányzatokat, illetve nézőpontokat mutatok be, amelyek 
mentén állatokat érintő kérdésekkel foglalkoztak geográfusok. Utóbbiak bemutatásakor a tágabb kontextusba helyezéssel egyrészt a hazai földrajztudományban kevésbé ismert irányzatok létjogosultságára hívom fel a figyelmet, másrészt, a diszciplináris kapcsolódási pontok felvillantásával a tanulmány - remélhetőleg - az újfajta állatföldrajzi kutatások hazai kibontakozását is elősegíti.

\section{A természettudományos állatföldrajz a 18. századtól a 20. század közepéig}

Az első egyetemi földrajzi tanszéket 1825-ben hozták létre a berlini egyetemen, amelynek vezetésével az egyetem 1820-ban kinevezett első földrajzprofesszorát, CARL RITTERt (1779-1859) bízták meg. Ritter az újonnan intézményesüló diszciplína feladatát a Teremtés tanulmányozásában látta (GYURIS F. 2020). A geográfia céljának ilyenfajta megjelölése igazodott a korszellemhez; Isten mint az ember által megismerhetô természeti törvények megalkotója fontos tényezője volt a tudományos gondolkodásnak (Isten, a természet és a tudomány változó viszonyáról l. LivingSTONE, D. 1992; DASTON, L. 1998).

A világ különböző pontjain élő fajok „leírása”, rendszerezése jól példázta a 18-19. századi természettudósoknak a Teremtés minél pontosabb megismerésére irányuló szándékát. Az élővilágról folyamatosan gyarapodó ismeretek miatt a különböző fajok földrajzi eloszlásával kapcsolatos - sokáig mellőzött - kérdések is egyre inkább előtérbe kerültek. A mellőzöttség hátterében leginkább az az ókorig visszavezethetô elképzelés állt, ami szerint a Földön a teremtés folyamata már lezárult, az ennek eredményeképp létrejött fajok változtathatatlannak tekinthetők. Az egymástól nagy földrajzi távolságban élő, sok esetben hasonló fajok jelenlétét magyarázó kezdeti elméletek ehhez az elképzeléshez igazodtak. A svéd természettudós, CARL VON LiNNÉ (1707-1778) például azt feltételezte, hogy a különböző fajok egy kiemelkedo „Paradicsomi Hegy”-ről származnak. Linné elképzelése mellett azonban egyre több elmélet született a fajok földrajzi elterjedéséról a 18. század második felében. Volt, amely egy, és volt, amely több teremtési eseményt feltételezett; volt olyan, amely a vándorlásnak tulajdonított kiemelt szerepet, és olyan is, amelyben már a környezet hatása is fontos tényezőként szerepelt (LARSON, J. 1986; BRIGGS, J. C.-Humphries, C. J. 2004).

Valamennyi átfogó jellegú elmélettel kapcsolatban azonban hamar megfogalmazódtak különböző kritikák; voltak olyan jelenségek, amelyekre egy-egy adott elmélet nem szolgált kielégítő magyarázattal. EBERHARD August WiLHELM VON ZimMERMANN (1743-1815) német természettudós arra hívta fel a figyelmet, hogy kevésbé átfogó jellegú problémák megoldásához is további adat-, illetve információgyújtésre kellene összpontosítaniuk a természettudósoknak. Ebben a szellemiségben keletkezett Zimmerman háromkötetes (1778 és 1783 között megjelent) munkája, a Geographische Geschichte des Menschen und der vierfüßigen Tiere („Az ember és a négylábú állatok földrajzi története”). A három kötet össz-terjedelmének több mint fele katalógusszerú leírás az állatokról, aminek alapján főleg a harmadik kötetben fogalmazott meg általánosabb következtetéseket. Zimmermann öt fő állatföldrajzi régiót határozott meg: Európát, Ázsiát, Afrikát, Amerikát és a Dél-Csendesóceán nagyobb szigeteit (LARSON, J. 1986). Eredményeit - akkoriban újdonságnak számító módon - térképen is ábrázolta (a Geographische Geschichtében közölt térkép egy korábbi, 1777-es munkájában szereplő térkép átdolgozott változata) (CAMERINI, J. 1993).

Zimmermann említett múveit követően a 19. század második negyedéig állatföldrajzi munkákban ritkán jelentek meg térképi ábrázolások, jóllehet a tematikus térképek készítése egyre elterjedtebbé vált más tudományterületeken, például a növényföldrajzban (CAMERINI, 
J. 1993). Heinrich Berghaus (1797-1884) Alexander von Humboldt (1769-1859) Kosmos („Kozmosz”) címú múvéhez készített tematikus atlaszának 1848-ban megjelent második kötete azonban már az állatvilág földrajzáról is 10 dupla oldalnyi térképet tartalmaz (Berghaus, H. 1848; PAPP-VÁRY Á. 2020).

Kiemelendő ugyanakkor, hogy többnyire csak szöveges formában, de már a 18. század végén, illetve a 19. század első felében gyakran határoltak le állatföldrajzi régiókat az állatok földrajzi eloszlása alapján. CHARLES DARWIN (1809-1882) és ALFRED RuSSEL WALLACE (1823-1913) természetes szelekciós elméletének kidolgozásában is fontos szerepet játszott az állatfajok földrajzi eloszlásának vizsgálata (CAMERINI, J. 1993). A két természettudós egymáshoz nagyon hasonló elméletét - Darwin közbenjárására, aki Wallace elméletének kéziratát akkor kapta meg, amikor ő maga már „A fajok eredete” címen ismert múvén dolgozott - 1858. július 1-jén mutatták be a londoni Linné Társaságban, majd később a társaság zoológiai folyóiratában is megjelentették (DARWIN, C. - WALLACE, A. 1858).

WALLACE kapcsán érdemes kiemelni, hogy az 1830-ban alapított Brit Királyi Földrajzi Társaság (RGS) anyagilag is támogatta, illetve a Társaság folyóirataiban 13, az Amerikai Földrajzi Társaság folyóiratában további egy cikke jelent meg. Az állatok földrajzával az említett cikkek közül több is foglalkozik. A brit természettudós emellett számos állatföldrajzi témájú tanulmányt publikált zoológiai folyóiratokban. Mindazonáltal állatföldrajzi, illetve biogeográfiai munkái közül a könyvei emelendők ki: 1876-ban jelent meg a The Geographical Distribution of Animals (,Az állatok földrajzi eloszlása”), 1878ban a Tropical Nature and Other Essays („Trópusi természet és más esszék”), 1880-ban pedig az Island Life (,Szigeti élet”) címú múve (SHERmer, M. 2002; Smith, C. H. 2010).

A 19. század végi - 20. század eleji állatföldrajz nemzetközi tanulmányozásához jól használhatók forrásként az Annales de Géographie címú folyóirat 1892 és 1914 között évente megjelent, a földrajztudomány különböző területeinek eredményeit bemutató bibliográfiai számai, amelyek (5 év kivételével) elérhetők a francia felsőoktatási, kutatási és innovációs minisztérium támogatásával létrehozott, tudományos publikációkat tartalmazó online gyújteményből (Persée). Az 1891-ben alapított folyóirat PAUL VIDAL DE LA BLACHE (1845-1918) és a köréje szerveződő iskola képviselőinek tudományos fóruma volt (BERDOUlay, V. 2001). Fentebb említett bibliográfiai számaiban az állatföldrajz ('géographie zoologique') önálló fejezetként 1894 és 1899 között, a növényföldrajzzal együtt ('géographie botanique et zoologique') pedig 1903 és 1906, illetve 1910 és 1914 között jelent meg. A bibliográfiákban felsorolt állatföldrajzi tanulmányok döntô része az állatok földrajzi eloszlásával foglalkozik, a cikkek többségét nem földrajztudományi folyóiratokban publikálták.

Az 1. táblázatban az Annales de Géographie említett számai, továbbá PHILO, C. (1995) és Wolch, J.-EMEL, J. - WILBERT, C. (2003) tanulmányai alapján gyújtöttem össze a századforduló környékén a földrajztudományi folyóiratokban megjelent állatföldrajzi témájú cikkeket. A korszak tudományos világa a jelenlegitól eltért abban, hogy a nemzetközi tudománynak a német, a francia és az angol egyaránt fő nyelve volt, a táblázatban szereplő folyóiratokban is ezeken a nyelveken írt publikációk szerepelnek. Bár a felsorolás nem teljes körú, ugyanakkor a cikkek szerzőiról általában megállapítható, hogy többségük nem földrajztudományi kötődésű volt, az utókor elsősorban nem geográfusként tekint rájuk. Kivételnek leginkább Theodor Arldt (1878-1960) mondható, akit - kevéssé sikeres tudományos karrierje ellenére - a paleobiogeográfia egyik úttörőjeként tart számon az utókor (EBACH, M. C.-Dowding, E. M. 2017).

Az Annales de Géographie bibliográfiai számai alapján a korszakban nagyobb ívû, az állatföldrajzot átfogóan tárgyaló munkák is megjelentek. Ezek közül példaként megemlíthetô a zoológus JACOBI ARNOLD 1903-ban publikált Tiergeographie („Állatföldrajz”) címú 


\section{1. táblázat - Table 1}

Földrajzi folyóiratokban megjelent állatföldrajzi munkák a 19. és 20. század fordulójának környékén (saját gyújtés az Annales de Géographie címú folyóiratnak

a Persée-gyújteményéből online elérhetői számai,

továbbá PHILO, C. 1995 és Wolch, J. et al. 2003 tanulmányai alapján)

Zoogeographical works published in geographical journals

around the turn of the $19^{\text {th }}$ and $20^{\text {th }}$ centuries (own collection based on the issues of

Annales de Géographie, which are available online

from the PERséE collection, PhILO, C. 1995 and WolCh, J. et al. 2003)

\begin{tabular}{|c|c|c|c|}
\hline $\begin{array}{l}\text { A folyóirat } \\
\text { neve }\end{array}$ & A megjelenés éve & Szerző & Téma \\
\hline Ausland & 1892 & NEHRING, A. & emlősök Kelet-Oroszországban \\
\hline \multirow{2}{*}{$\begin{array}{l}\text { Scottish } \\
\text { Geographical } \\
\text { Magazine }\end{array}$} & 1893 & GUPPY, H. B. & vízi állatok földrajzi eloszlása \\
\hline & 1896 & Eagle Clarke, W. & madarak vonulásának földrajza \\
\hline \multirow[t]{2}{*}{$\begin{array}{l}\text { Geographical } \\
\text { Journal }\end{array}$} & $\begin{array}{l}\text { 1894-1897 között } \\
7 \text { egymást követő cikk }\end{array}$ & SClATER, W. L. & szárazföldi emlősök földrajza \\
\hline & 1894 & MöBIUS, K. & $\begin{array}{l}\text { bálnák földrajzi eloszlása és szoká- } \\
\text { saik (a cikk a Verhandlungen } \\
\text { der Gesellschaft für Erdkunde zu } \\
\text { Berlin folyóiratban is megjelent) }\end{array}$ \\
\hline $\begin{array}{l}\text { Annales de } \\
\text { Géographie }\end{array}$ & 1894 & PRIEM, $\mathrm{F}$ & ausztrál emlôsfauna \\
\hline \multirow{2}{*}{$\begin{array}{l}\text { Petermanns } \\
\text { Geographische } \\
\text { Mitteilungen }\end{array}$} & 1909 & ARLDT, T. & állatföldrajzi régiók és rétegek \\
\hline & 1914 & KOWARZIK, R. & vadjuhok elterjedése \\
\hline \multirow{2}{*}{$\begin{array}{l}\text { Annals of the } \\
\text { Association } \\
\text { of American } \\
\text { Geographers }\end{array}$} & 1912 & Ruthven, A. G. & $\begin{array}{l}\text { Dél-Vera-Cruz-i hüllő- és } \\
\text { kétéltúfauna }\end{array}$ \\
\hline & 1913 & SHELFORD, V. E. & $\begin{array}{l}\text { a párologtatás állatföldrajzi } \\
\text { jelentősége }\end{array}$ \\
\hline $\begin{array}{l}\text { Geographische } \\
\text { Zeitschrift }\end{array}$ & $\begin{array}{l}\text { 1913-ban } 5 \text { egymást } \\
\text { követő cikk }\end{array}$ & HESSE, R. & $\begin{array}{l}\text { az állatok szaporodásának } \\
\text { ökológiai alapjai }\end{array}$ \\
\hline
\end{tabular}

múve, az 1911-ben megjelent Atlas of Zoogeography („Állatföldrajzi atlasz”), amelyet JoHN George Bartholomew kartográfus, William Eagle Clarke, a Skót Királyi Múzeum Természettudományi Részlegének gondozója, és segédje, PerCy Hall Grimshaw készített, valamint a Scottish Geographical Magazine szerkesztőjének, Marion Newbiginnek az 1913-as Animal Geography („Állatföldrajz”) című könyve. Ez utóbbi múre az állatföldrajz történetével az elmúlt néhány évtizedben, döntóen angolszász geográfusoktól megjelent munkák (pl. Wolch, J. et al. 2003; UrbaniK, J. 2012; Colombino, A. 2020) rendszeresen hivatkoztak, jóllehet a múvet 1914-ben az Annales de Géographie-ban röviden bemutató GeRMAIN, L. (1914, p. 95.) „inkább a fó biológiai miliőket leíró, nem igazán állatföldrajzi” tanulmányként jellemezte. Az Animal Geography előszavában Newbigin, M. I. (1913) kifejtette, hogy munkájának célja az állatok földrajzi eloszlásával kapcsolatos tények bemutatása a földrajzos hallgatók számára befogadható módon, amit elsősorban azért tartott szükségesnek, mert a témával mindaddig a geográfusok lényegesen kevesebbet foglalkoztak, mint például a növényföldrajzzal. Az állatföldrajzi ismeretek többségét akkoriban zoológiai tankönyvek tartalmazták, azok azonban nem földrajzos néző- 
pontot tükröztek. NEWBIGIN mindenekelőtt azért érezte magát alkalmasnak arra a feladatra, hogy ezt az űrt pótolja, mert ó maga is kezdetben a biológia irányából közelített a földrajz felé.

A NEWBIGIN által az állatföldrajz általános helyzetéról felvázolt képhez sok szempontból illeszkedő megállapításokat tett a hazai állatföldrajz vonatkozásában FODOR FERENC (1887-1962) a magyar földrajztudomány történetét a kezdetektől az 1940-es évek közepéig-végéig feldolgozó munkájában. Szerinte a növényföldrajzi kutatásokhoz képest ,(k)isebb jelentőségúek és sokkal kisebb terjedelmúek a magyar föld állatföldrajzára vonatkozó kutatásaink. Ami van is ilyen irányú eredményünk, abban is elég kevés a földrajzi vonatkozás" (FoDOR F. 2006, p. 328.). Bár FODOR nem említi, de a budapesti Tudományegyetem Állatrendszertani Intézetének vezetője, DUDICH ENDRE 1942-ben az általa szerkesztett $A z$ állat és élete (második rész) címú könyvében $A$ szárazulatok állatföldrajzáról értekezett egy fejezetben (DuDICH E. [szerk.] 1942), amelyet kibóvítve az 1950-es években állatföldrajzi egyetemi jegyzetként is kiadtak (BERCZIK Á. 1971). DuDICH munkái a hazai állatföldrajzi, illetve biogeográfiai szakirodalomban a későbbiekben is alapmúnek számítottak (KÁDÁR L. 1965; WÉBER M. 1973; SzÉKY P. 1989 alapján).

Az állatföldrajz kapcsolatai a biológiai tudományokkal Magyarországon - akárcsak külföldön - élénkebbek voltak, mint magával a földrajztudománnyal. Ennek kapcsán magyar vonatkozása miatt érdemes megemlíteni a Kaliforniai Állami Egyetemen a biológiai tudományok professzoraként oktató UdVARDY MikLóst, akinek 1969-ben megjelent Dynamic Zoogeography. With special reference to land animals címú könyvét Magyarországon 1983-ban adtak ki Dinamikus állatföldrajz címmel (UdVARDY M. 1983). UdVARDY múvét a Geographical Review-ban BENNETT, C. F. (1971), a Kaliforniai Egyetem földrajzprofesszora ismertette, aki a könyv egyik legfőbb hiányosságát a földrajzosok által írt biogeográfiai munkák figyelmen kívül hagyásában látta.

Bennetr, C. F. (1960) és a Tasmaniai Egyetem földrajzoktatója, DAVIES, J. L. (1961) egyaránt megállapította, hogy az állatföldrajzzal geográfusok mindaddig alig foglalkoztak, helyettük zoológusok, ökológusok, paleontológusok munkái határozták meg a tudományterületet. Míg DAVIES szerint ezt az állapotot az állatföldrajzi kérdésekkel foglalkozó kutatók képzésének átalakításával kellett volna orvosolni (elképzelése szerint a geográfus hátterúek előnyös helyzetben lettek volna), addig BENNETT egy új állatföldrajzi irányzat kidolgozását szorgalmazta. Az általa javasolt és kulturális állatföldrajznak hívott irányzat az állatok és az emberi kultúrák közötti kölcsönhatásokra összpontosított (volna) (például az ember szerepe bizonyos fajok elterjesztésében vagy a megélhetés érdekében űzött vadászat és halászat), ami a biológiai tudományokban kevésbé jártas geográfusok számára is potenciálisan vonzó kutatási terepet jelentett (volna). BENNETT javaslata azonban nem tekinthető kifejezetten újszerúnek, ha figyelembe vesszük, hogy a földrajztudományon belül addigra például a háziasítás földrajzi vonatkozásai kapcsán már több munka is született (pl. HaHn, E. 1896; SAUER, C. O. 1952).

\section{A háziasítás, illetve a háziállatok megjelenése a földrajztudományi munkákban}

Az állattenyésztésnek, illetve az állatok háziasításának több ezer éves múltja van. Kezdetben vélhetôen a véletleneknek volt benne döntó szerepe - a kutyák például valószínúleg „önmagukat kezdték háziasítani” (TRACHSEL, M. 2017, p. 108.) -, majd az ember a történelem folyamán egyre tudatosabban kontrollálta saját céljainak megfelelően a „háziállatok" szaporodását. Az állattenyésztés fokozódó jelentőségét jelezte, hogy például 
Nagy-Britanniában a 19. században az állattenyésztőknek folyóiratai, illetve társaságai múködtek, továbbá rendszeresen szerveztek kiállításokat és versenyeket (RADICK, G. 2009).

Az állattenyésztés irodalma és az állattenyésztők különböző találkozói iránt DARWIN is komoly érdeklődést mutatott (RADICK, G. 2009), galambok tenyésztésével pedig ô maga is kísérletezett (ENDERSEY, J. 2009). Az állattenyésztés kapcsán szerzett tapasztalatai a legismertebb On the Origin of Species by Means of Natural Selection („A fajok eredete”) címú 1859-es, illetve részletesebben az 1868-ban publikált The Variation of Animals and Plants under Domestication címú múvében is megjelentek (az utóbbit magyarul „Állatok és növények változásai háziasításuk során" címmel adták ki).

A 19. század második felében többen, főként természettudományi, illetve történettudományi megközelítésben tanulmányozták a háziállatok eredetét (CAULLERY, M. 1897). Az ő munkáikat tekintette át HAHN, E. is, akinek 1896-ban megjelent fô múve, a Die Haustiere und ihre Beziehungen zur Wirtschaft des Menschen („A háziállatok és kapcsolatuk az ember gazdaságával") földrajztudományi megközelítésben foglalkozott átfogóan a háziállatok kérdéskörével. HAHN 1886-ban védte meg a Lipcsei Egyetemen állatföldrajzi témájú doktori munkáját, majd követte a Berlini Egyetemre természetföldrajzi profeszszornak kinevezett FERDINAND vON RICHTHOFENt, akinek a javaslatára 1887-ben kezdett foglalkozni a háziállatok eredetével (ENGELBRECHT, T. H. 1928, idézi WeSt, R. C. 1990).

HAHN legfóbb tudományos eredménye az volt, hogy megdöntötte azt a lényegében az ókor óta elterjedt vélekedést, amely a gazdasági fejlődés történetében három egymást követő szintet különített el: primitív vadászó-gyújtögető életmód, nomád pásztorkodás, mezőgazdaság. Történelmi és néprajzi anyagokra alapozta azt az álláspontját, amely szerint az állatok és a növények háziasítása eredményeképpen lettek a vadászó-gyújtögető életmódot folytató emberek földmúvesek és állattenyésztők; a nomád pásztorok pedig csak egyfajta oldalhajtásnak tekinthetők a mezőgazdaság történetében. Az állatok háziasításában és a mezőgazdaság történetében HAHN a vallás és a mágia szerepét hangsúlyozta, a korabeli gazdaságtörténészek többsége azonban ezzel a vélekedéssel nem értett egyet (WEST, R. C. 1990).

HAHN 1896-ban megjelent munkájáról a szintén Richthofen-tanítvány ALFRED HETTNER (1859-1941) írt értékelést a Geographische Zeitschrift folyóiratba (HETTNER, A. 1897). A múvet összességében sok szempontból túl szubjektívnek, nem kellően megalapozottnak tartotta, ugyanakkor számos értékes - többek között az előbbiekben ismertetett - gondolatot emelt ki belőle (HeTtner, A. 1897, idézi West, R. C. 1990). A német geográfusok, többek között HAHN és HETTNER gondolatai később jelentős hatást gyakoroltak az amerikai kulturális földrajzos Carl Sauer és a köréje szerveződő Berkeley-iskola munkásságára is (Kersten, E. W. 1982; West, R. C. 1990; Livingstone, D. 1992; DunCan, J. 2009).

SAUER munkásságának központi eleme annak vizsgálata volt, milyen hatással vannak az emberek környezetükre, hogyan alakítják át a természeti tájat kultúrtájjá. Az állatföldrajz történetével foglalkozó tanulmányok (WoLCH, J. et al. 2003; URBANIK, J. 2012) SAUER életmúvéből elsősorban az 1952-ben eredetileg Agricultural origins and dispersals („A mezőgazdaság eredete és elterjedése") címen (későbbi kiadásokban Seeds, spades, hearths and herds [,,Magok, ásók, szívek és csordák”]) megjelent munkáját szokták kiemelni. SAUER ebben a múvében többek között azt vizsgálta, hogy milyen szerepet játszott az állatok háziasítása a kultúrtájak kialakításában (URBANIK, J. 2012). A háziasítás kapcsán SAUER elfogadta HAHN érvelését és elutasította azt a vélekedést, amely a domesztikáció hátterében kizárólag tudatos gazdasági motivációkat feltételezett (SAUER, C. O. 1952). Mindazonáltal, az utókor az időközben folyamatosan bővülő régészeti ismeretanyagra alapozva cáfolta HAHN és SAUER azon vélekedését, amely szerint az állatok háziasításában a rituális szempontok lettek volna az elsődlegesek (RodRigue, C. M. 1992; Anderson, K. 1998; Vigne, J.-D. 2011). 
SAUER és a Berkeley-iskola kulturális földrajzának háttérbe szorulásában azonban nem ez játszotta az elsődleges szerepet, hanem az, hogy a tudományterület nem volt képes alkalmazkodni a társadalomtudományok második világháborút követő hullámaihoz (pozitivista kvantitatív vizsgálatok, majd humanista és posztmodern szemlélet) (PALACZKI, B. 2016). Mindazonáltal a saueri gondolatok - elsősorban SAUER iskolateremtő egyéniségének köszönhetően (MATHEWSON, K. 2011) - nem merültek teljes feledésbe.

A SAUER-tanítványok közül többen is foglalkoztak a későbbiekben kulturális földrajzi megközelítésben háziállatokkal, illetve a háziasítással: például FredERICK J. SimOONS (GADE, D. W. 1987), valamint a Berkeley-n az 1950-es években ösztöndíjjal tanuló brit Robert Arthur Donkin (Baker, A. R. H. 2019) és David Russel Harris (Shennan, S.-Clout, H. 2017). SAUER munkássága közvetlen tanítványain kívül is több geográfusra volt hatással (WoLCH, J. et al. 2003; URBANIK, J. 2012). SAUER azon kevés geográfusok egyike, akire JARED DiAMOND is hivatkozott 1997-ben megjelent, Pulitzer-díjat nyert Guns, Germs and Steel: The Fates of Human Societies címú (magyarul „Háborúk, járványok, technikák") könyvében. Diamond ebben a múvében a korai társadalmi, gazdasági fejlődésben kiemelt szerepet tulajdonított a háziasítható fajok jelenlétének. Könyvének fogadtatása vegyes volt geográfus körökben, a munka környezeti determinista vonásaira hivatkozva többen bírálták (LivingSTONE, D. N. 2011; WiLSON, R. M. 2013).

Érdemes továbbá megemlíteni, hogy SAUER - fóként korai munkáiban - épített az Európában is komoly hagyományokkal bíró tájkutatás irodalmára (PROBÁLD F. 1995; Shaw, D. J. B.-OldField, J. D. 2007; EszenYi O. 2016). Az állatföldrajz történetével foglalkozó - döntően angolszász - munkák azonban az európai tájföldrajzi, illetve regionális földrajzi kutatások kapcsán általában mindössze azt rögzítik, hogy a fauna bemutatása is többé-kevésbé részét képezte ezeknek a kutatásoknak. URBANIK, J. (2012) ugyanakkor arra is kitért, hogy bár nem központi témaként, de például Vidal de la Blache a halálát követően megjelent (francia nyelven 1922-ben, angolul 1926-ban) The Principles of Human Geography („Az emberföldrajz alapelvei”) címú múvében foglalkozott igavonó állatokkal, illetve a sertéseknek a közép-európai kultúrában betöltött szerepével (URBANIK, J. 2012).

A haszonállatok - leginkább földrajzi eloszlásuk - vizsgálata a mezőgazdaság földrajzával foglalkozók számára is fontos kutatási terepet jelentett. Az állatföldrajzhoz képest a mezőgazdaság földrajza a regionális földrajzi munkákban is jellemzően hangsúlyosabb szerephez jutott. A mezőgazdaság földrajzát lényegében az 1970-es évekig kizárólag a különböző agrártevékenységek térbeli eloszlásának vizsgálata határozta meg, kutatási témáinak spektruma - sok más tudományterülethez hasonlóan - ezt követóen szélesedett ki (Robinson, G. M. 2018).

\section{Újfajta állatföldrajz(ok) kibontakozása}

Az 1960-as évek végén és az 1970-es években számos olyan politikai-társadalmi-gazdasági esemény történt, illetve változás zajlott elsősorban a „nyugati” világban (például polgárjogi mozgalmak, diáklázadások), ami hatással volt a tudomány alakulására, ugyanakkor megjegyzendő, hogy sok esetben a tudomány is hatott az említett eseményekre, változásokra (AGAR, J. 2008; Heymann, M. 2017). A tudományos világ egészét érintő változások a földrajztudományon belül, illetve az állatokkal foglalkozó kutatások hangsúlyeltolódásai kapcsán is éreztették hatásukat.

A második világháborút követő hidegháborús korszak körülbelül első másfél évtizedének tudományos világát az úgynevezett ‘Big Science’ határozta meg, amelyben a tudomány mindenekelőtt a katonai és modernizációs célok elérését szolgálta. A társadalomtudo- 
mányokat ebben a korszakban a kvantitatív, természettudományos módszerek térnyerése jellemezte, illetve a „nyugati világban” gyakran hangoztatták az ideológiamentesség jelentőségét is (AgAR, J. 2008; Heymann, M. 2017).

A biogeográfián belül például a korszak egyik jellegzetes „terméke” a kanadai születésú MacArThur, R. H. és az amerikai WiLSON E. O. 1967-ben publikált The Theory of Island Biogeography („A sziget-biogeográfia elmélete”) múve, amelyben a szerzőpáros az egyes szigetek fajgazdagságára, nagyságára és szárazföldtől való távolságára vonatkozóan fogalmazott meg matematikai összefüggéseket. A mú megjelenését másfél évtizeddel megelőzően az amerikai Cornell Egyetemen doktoráló MunROE, E. G. rendkívül hasonló megállapításokat tett, ugyanakkor az ő gondolatainak elterjedését többek között az akadályozta, hogy akkoriban még a kvantitatív modellek iránt lényegesen kevésbé volt nyitott a tudományos közösség (BROwN, J. H.-LomoLiNo, M. V. 1989).

A társadalomföldrajzban a „kvantitatív forradalom” az USA-ban bontakozott ki és leginkább itt, illetve Nagy-Britanniában éreztette hatását (BARNES, T. J. 2004; GYURIS F. 2014). A „,forradalom” által tértudományként pozicionált földrajzzal szemben azonban az 1960-as végétől kezdődően számos kritika fogalmazódott meg, amelyek mentén új irányzatok bontakoztak ki a diszciplínán belül (Kitchin, R. 2006; Philo, C. 2017).

Az egyik új irányzat a humanisztikus földrajz volt, amelynek képviselői a tértudományi földrajz legfőbb problémáját az emberi egyéniség racionális döntéshozóvá, térképi pontokká, táblázatokban szereplő számokká történő redukálásában látták (KITCHIN, R. 2006; Sharp, J. 2009; PhILO, C. 2017). A humanisztikus földrajz azonban összességében rendkívül heterogén irányzatként értékelhető, múvelőinek közösségét inkább az határozta meg, hogy mivel szemben fogalmazták meg az új irányzatot, mintsem az új irányzat tartalma. A humanisztikus földrajz egyik legfőbb képviselője, $Y i-F u$ Tuan például a földrajz és a bölcsészettudományok közötti kapcsolatok erősítésében látta a humanisztikus földrajz célját (ENTRIKIN, J. N.-TEPPLE, J. H. 2006).

Ez a szellemiség érződik YI-Fu TUAN Dominance and affection: The making of pets („Uralkodás és vonzalom: a kiskedvencek létrehozása”) címú munkáján is, amelyben elsősorban pszichológiai szempontból vizsgálta a természet - beleértve bizonyos emberi lények - örömszerzési és múvészeti céllal történő kizsákmányolását. A könyv bemutatja, hogyan tette a mindenkori elit paternalizmusa például a kerteket, a szökőkutakat, az állatokat, a gyermekeket, a nőket és a rabszolgákat „kiskedvencekké”, az uralkodás és a vonzalom tárgyává (TUAN, Y-F. 1984).

Bár az elóbb említett csoportok kiszolgáltatottsága számos tekintetben ma is létezik, a 20. század második felében több olyan kezdeményezés, társadalmi mozgalom indult el, illetve erősödött fel, amelyek több-kevesebb eredménnyel változást sürgettek az említett csoportok helyzetében. A feminista mozgalmak korszakolásában például az 1960-as és 1970-es éveket gyakran a „második hullám” elnevezéssel illetik (a „hullámok” közül az első a 19. század közepe és a korai 20. század közötti időszakban zajlott, a harmadik pedig az 1990-es években kezdődött EdELMAN, M. 2001 szerint). Az 1970-es és 1980-as években a gyermekjogok terén is jelentős fejlődés történt (ToMKA, B. 2009), továbbá a 20. század második felében erősödtek fel a környezetvédelmi (RoOTEs, C. 2004) és az állatjogi mozgalmak (Nocella II., A. J. et al. 2014).

Az állatjogi mozgalmakkal összefüggésben megemlítendő, hogy a 20. század második felében az állatok viselkedésével foglalkozó tudományterületek eredményei is jelentősen bővültek. 1973-ban például a fiziológiai és orvostudományi Nobel-díjat egy új tudományterület, az „összehasonlító viselkedéstan” vagy más néven etológia „legkiemelkedőbb alapítói”, KARL VON FRISCH, KONRAD LORENZ és NiKOLAAS TinBERGEN kapták megosztva „az egyéni és társas viselkedési mintázatok szerveződésével és kiváltásával kapcsolatos 
felfedezéseikért" (Nobelprize.org 2021). Mindezek a felfedezések az emberi viselkedési mintázatok tanulmányozásához is hasznosnak bizonyultak, és hozzájárultak annak az éles határvonalnak a halványulásához, amely korábban jellemezte az emberek és az állatok között meglévő különbségek értelmezését (megjegyzendő ugyanakkor, hogy a történelem folyamán gyakori jelenség volt bizonyos emberi csoportok állatokhoz való hasonlítása, „dehumanizációja”, amiben a velük szemben a maga felsőbbrendűségét hirdető csoport tudományos közössége is komoly szerepet vállalt - JAHODA, G. 2014; CALARCO, M. R. 2020). Az ember-állat határvonal halványulásának fényében nem meglepó, hogy egyre több filozófus is hangsúlyosabban kezdett foglalkozni az állatok helyzetével.

Peter Singer ausztrál filozófus Animal Liberation címú munkája 1975-ben (magyarul „Az állatok felszabadítása" címen), Tom Regan amerikai filozófus The Case for Animal Rights („Az állatjogok ügye”) címú múve pedig 1983-ban jelent meg. Ezek a munkák nemcsak az állatok jogaiért küzdő aktivisták céljainak adtak hangot (megjegyzendő, hogy ekkoriban alapítottak számos állatvédő szervezetet), hanem a tágabb tudományos közösséget is ösztönözték az emberek és az állatok közötti viszonnyal foglalkozó kutatásokra (Shapiro, K.-DeMello, M. 2010; Calarco, M. 2020).

$\mathrm{Az}$ 1970-es években az állatokkal folytatott terápiák is egyre népszerúbbek lettek, egyre többen foglalkoztak tudományos igénnyel az állatok emberi egészségre és jóllétre gyakorolt hatásával (Hines, L. M. 2003; MoRRison, M. L. 2007). LEO K. BuSTAD, RoBERT K. Anderson, Stanley Diesch és William McCulloch állatorvosok, illetve Michael MCCulLOCH pszichiáter 1977-ben létrehozták a Delta Foundationt, amely 1981-tôl Delta Society néven múködött tovább, és az emberi egészség állatok segítségével történő javítására fókuszált (WSU 2021).

A szervezet tudománytörténeti jelentőségét az adja, hogy 1984-ben megjelentették a The Journal of the Delta Society címú folyóiratot, amely a szervezet által ugyanabban az évben megrendezett konferenciának az anyagait tartalmazta. Az interdiszciplináris konferencia (és ezáltal a folyóirat) célja az volt, hogy meghatározza az „ember-állat kötelék” kapcsán vizsgálandó kutatási kérdéseket és a vonatkozó módszertanokat. A folyóirat mindössze két számot élt meg, ugyanakkor az utódjának tekinthető Anthrozoös címú folyóirat 1987 óta rendszeresen megjelenik (2017-ig évente 4, 2018-tól évente 6 számmal) (RowAN, A. N. 1987; Hines, L. M. 2003).

Az állatok és az emberek közötti viszonnyal foglalkozó folyóiratok száma azóta jelentősen nőtt (például Society \& Animals, Humanimalia, Journal for Critical Animal Studies), és egyre több tudományterület (politikatudomány, jogtudomány, földrajztudomány) képviselői körében megfigyelhető a téma iránti fokozódó érdeklődés (SHAPIRO, K.DeMello, M. 2010). Ennek következtében egy új interdiszciplináris kutatási terület, az úgynevezett Animal Studies (magyarra leginkább állattanulmányokként fordítható) kibontakozásának lehet(t)ünk tanúi. Az Animal Studies azonban nem tekinthető egységesnek, különböző változatai léteznek, amelyek közül jelentőségénél fogva a Human-Animal Studies-t (HAS, ,ember-állat tanulmányok”) és a Critical Animal Studies-t (CAS, ,kritikai állattanulmányok") érdemes kiemelni. A két változat sok hasonlóságot mutat egymással, mindkettő fontos vizsgálati témájának tekinti az állatok emberi társadalmakban betöltött szerepét. A CAS esetében azonban kiemelt jelentősége van annak, hogy képviselői antikapitalista szellemiségben tevékenykednek; céljuk, hogy fellépjenek az állatokkal szemben megnyilvánuló megkülönböztetés, illetve a velük szembeni erőszak ellen (CAlarco, M. 2020).

A földrajztudományon belül elsôsorban az utóbbi irányzat képviselői „fedezték fel újra” és hivatkoznak egyfajta előképként anarchista geográfusok, különösen ÉLisÉE RECLUS (1830-1905) és PJOTR AleKsZEjevics KropotKin (1842-1921) 19-20. század fordulójá- 
nak környékén megjelent munkáira (WHITE, R. J. 2015). RECLUS, É. 1901-ben a Humane Review-ban publikált, On Vegetarianism („A vegetarianizmusról”) címú munkájában a vegetarianizmus létjogosultságát elsősorban az érzelmekre ható történetekkel, megállapításokkal próbálta igazolni. KROPOTKIN, P. A. (1908) a Mutual Aid: A Factor of Evolution címú könyvében (magyarul 1908-ban: „A kölcsönös segítség mint természettörvény”) párhuzamot von az állatvilágban és az emberi társadalomban megfigyelhető kölcsönös segítségnyújtás között, és elsősorban utóbbi jelentőségét igyekszik igazolni.

Az Animal Studies szellemiségéhez illeszkedő, az ember-állat viszonyt középpontba helyező földrajztudományi munkák száma az 1990-es években indult növekedésnek. Az újfajta állatföldrajz kibontakozásának egyik kulcseseményeként értékelhető, hogy 1995-ben az Environment and Planning D: Society and Space címú folyóirat 6. száma Wolch, J. és EMEL, J. amerikai geográfusok vendégszerkesztésében jelent meg Bringing the animals back in („Az állatok visszahozása”) címmel. A szerkesztőpáros a szám előszavában felhívta a figyelmet arra, hogy a társadalomelmélet túlzott emberközpontúságán változtatni kellene, hiszen az állatok központi szerepet játszanak például a környezeti fenntarthatóság, a gazdasági és a társadalmi rend, a személyes kapcsolatok, illetve az egyéni identitás, valamint az igazságosságról és erkölcsről alkotott koncepciókban. A folyóiratszámmal a szerkesztők azt kívánták elérni, hogy a terek és helyek értelmezésébe „visszahozzák az állatokat”. Ennek megfelelően nem meglepő, hogy a folyóiratszámba publikáló szerzők döntő többsége - intézményi affiliációját tekintve - geográfus.

Részben az említett folyóiratszám néhány cikkének újraközlésével (és átdolgozásával) adták ki 1998-ban az említett szerkesztők munkájaként az Animal Geographies („Allatföldrajzok”) címú könyvet (Wolch, J.-EMEL, J. 1998). Ugyanebben az évben jelent meg (PHILO, C. és Wolch, J. vendégszerkesztésében a Society \& Animals folyóirat tematikus különszáma, amelynek középpontjában szintén a terek, a helyek, illetve az emberek és az állatok közötti kapcsolatok vizsgálata állt. Két évvel késóbb, 2000-ben publikálták az „újfajta” állatföldrajzi munkákban gyakran hivatkozott Animal Spaces, Beastly Places („Az állati terek, az állatok terei”) címú könyvet PHILO, C. és WILBERT C. (2000) szerkesztésében.

E könyv címében az újfajta állatföldrajz két fó fókuszterülete jelenik meg. Az állati terek (,,animal spaces”) azok a materiális (például települések, mezők, farmok, gyárak, állatkertek, laboratóriumok) és képzeletbeli, virtuális terek (például múvészeti alkotások), amelyekbe az emberi társadalmak az állatokat pozicionálják. Az újfajta állatföldrajz ennek kapcsán vizsgálja például, hogy hogyan határozzák meg társadalmilag az állatokat, hogyan használják őket étkezési célra, mi alapján minősítik némelyiket kiskedvencnek, míg másokat kártevőnek vagy érző lénynek különböző történelmi és földrajzi kontextusokban (Philo, C.-Wilbert, C. (eds.) 2000; Colombino, A. 2020).

Ezzel szemben, illetve emellett az ,állatok terei” (,beastly places”) az állatok maguk által kialakított, érzékelt, megélt terei. Az állat-ember viszony „állati oldalának” vizsgálata a tudományterület „more-than-human” szellemiség felé történő elköteleződése miatt is fontos (HodgetTs, T.-LoRimer, J. 2015), aminek lényegi eleme, hogy az állatokat, illetve általában véve a természetet az emberhez képest nem alsóbbrendú tényezőként ismeri el, az emberek és a körülöttük lévő világ kapcsolataira fókuszál (CALARCO, M. R. 2020).

A földrajztudomány azonban hagyományosan ,emberközpontú”, mint azt a magyarul társadalomföldrajznak hívott tudományterület idegen nyelvú megnevezései jelzik: angolul „,human geography”, franciául ,géographie humaine”, németül „Humangeographie”, illetve „Anthropogeographie” (az említett idegen nyelvú kifejezések tükörfordítása az „emberföldrajz”, ami - elsősorban francia mintára - a hazai földrajztudomány szovjeti- 
zálását megelőzően társadalomföldrajzi értelemben Magyarországon is elterjedt fogalom volt). Ennek fényében nem meglepő, hogy a társadalomföldrajz módszertani eszköztára az ,állatok tereinek” vizsgálatához szúkebb, mint az állati terek esetében. A ,állati nézőpontú" publikációk száma is alacsonyabb, jóllehet az utóbbi években növekedést mutat (HodgetTs, T.-LoRimer, J. 2015; Colombino, A. 2020).

Az „újfajta” állatföldrajz előbbiekben vázolt főbb munkái (az említett folyóiratszámok cikkei, illetve kötetek fejezetei is) - a szerzők affiliációját vizsgálva - szinte kizárólag angolszász szerzőkhöz köthetők. Az amerikai állatföldrajz kiemelt pozícióját jelzi továbbá, hogy az Amerikai Földrajzosok Szövetségén (Association of American Geographers) belül Julie Urbanik (Jody Emel tanítványa) és Monica Ogra 2009-ben megalapította az Állatföldrajzi Szakcsoportot (Animal Geography Specialty Group). Fontos ugyanakkor megjegyezni, hogy az „újfajta” állatföldrajzi tudástermelésbe az angolszász világon kívülről is egyre többen kapcsolódnak be (a francia vonatkozásokról 1. pl. BORTOLAMIOL, A.-RAYMOND, R.-SimON, L. 2017), jóllehet bizonyos térségekben - többek között Magyarországon ilyen témájú munkák egyelőre nem, illetve rendkívül kis számban születtek.

\section{Összefoglalás}

A geográfia intézményesülésétől napjainkig számos olyan földrajztudományi munka született, amelynek az állatok valamilyen szempontból lényeges elemét képezték. A 18-19. század természettudósai az állatok földrajzi eloszlására keresték a magyarázatot, különböző állatföldrajzi régiókat határoltak le. Többségüket nem elsősorban geográfusként tartja számon az utókor, jóllehet többen közülük már az intézményesülő földrajztudomány különböző fórumain is ismertették eredményeiket. Az állatok földrajzi eloszlásával foglalkozó, szúkebben értelmezett állatföldrajzra a későbbiekben is igaz maradt az a megállapítás, hogy a képviselőik döntő többsége nem földrajztudományi hátterú volt.

Az állatok térbeli eloszlása mellett egy másik, nagy múltra visszatekintő kutatási irányzat a háziállatok, illetve a háziasítás földrajzával foglalkozott. Ilyen munkák nemzetközileg nagyobb számban az 1950-es évektől kezdődően a Berkeley-iskola képviselőitől jelentek meg. A 20. század második felében azonban a Berkeley-iskola kulturális földrajza fokozatosan háttérbe szorult. Az állatokkal foglalkozó földrajztudományi kutatások spektruma az 1990-es évektől kezdődően szélesedett ki. Ennek hátterében a más tudományterületeken, illetve a társadalomban végbemenő változások nyomozhatók (például az állatok viselkedésével foglalkozó tudományterületek eredményeinek bővülése, állatjogi mozgalmak, állatok terápiás célú alkalmazásának terjedése, új társadalomelméletek).

Az újfajta állatföldrajzi kutatások középpontjában az ember-állat viszony áll. A tudományterület képviselói részére az ember által az állatok számára kijelölt valós és virtuális terek, valamint az állatok megélt terei, illetve ezeknek a metszetei egyaránt érdekes kutatási terepet jelentenek. A földrajztudomány az ilyen kérdések vizsgálatával az elmúlt évtizedekben formálódó új interdiszciplináris kutatási terület, az Animal Studies számára is érdemi mondanivalóval szolgál.

\section{Köszönetnyilvánítás}

A tanulmány az Innovációs és Technológiai Minisztérium Kooperatív Doktori Program Doktori Hallgatói Ösztöndíj Programjának a Nemzeti Kutatási, Fejlesztési és Innovációs Alapból Finanszírozott szakmai támogatásával készült. A kézirat korábbi változatához 
füzött értékes megjegyzéseiért köszönettel tartozom GYURIS FERENCnek, GYőRI RóBERTnek és az anonim lektoroknak.

\author{
VARGA GYÖRGY \\ ELTE TTK Társadalom- és Gazdaságföldrajzi Tanszék, Budapest \\ gyorgy.varga@ttk.elte.hu
}

\title{
IRODALOM
}

AgAR, J. 2008: What happened in the sixties? - The British Journal of the History of Science 41. 4. pp. 567-600.

AndERSON, K. 1998: Animal Domestication in Geographic Perspective. - Society \& Animals 6. 2.pp. 119-135.

ARLDT, T. 1909: Tierregionen und Tierschichten. - Petermanns Geographische Mitteilungen 55. pp. $223-225$.

BAKer, A. R. H. 2019: Robert Arthur Donkin (1928-2006) - Proceedings of the British Academy 172. pp. $115-139$.

BARNES, T. J. 2004: Placing ideas: genius loci, heterotopia and geography's quantitative revolution. - Progress in Human Geography 28. 5. pp. 565-595.

Bartholomew, J. G.-EAGle Clarke, W.-Grimshaw, P. H. 1911: Atlas of Zoogeography. - Edinburgh Geographical Institute, Edinburgh. 67 p. text 36 plates index.

Bassin, M. 1987: Friedrich Ratzel. - In: Freeman, T. W. (ed.): Geographers: Biobibliographical Studies 11. Continuum, London. pp. 123-132.

BENNETT, C. F. 1960: Cultural animal geography: an inviting field of research. - Professional Geographer 12. 5. pp. 12-14.

BennetT, C. F. 1971: Dynamic Zoogeography: With special reference to land animals. By Miklos D. F. Udvardy. - Geographical Review 61. 1. pp. 155-157.

BERCZIK Á. 1971: Dr. Dudich Endre. 1894-1971. - Hidrológiai Közlöny 51. 8-9. pp. 343-344.

Berdoulay, V. 2001: Geography in France: Context, practice and text. - In: Dunbar, G. S. (ed.): Geography: Discipline, profession and subject since 1870 - An international survey. Springer Science + Business Media, Dordrecht. pp. 45-78.

Berghaus, H. 1848: Physikalischer Atlas. Zweiten bandes. - Justus Perthes, Gotha. 234 p.

Bortolamiol, A.-RAYMOnd, R.-SimOn, L. 2017: Territoires des humains et territoires des animaux: éléments de réflexions pour une géographie animale. - Annales de Géographie 716. pp. 387-407.

Briggs, J. C.-Humphries, C. J. 2004: Early classics. - In: Lomolino, M. V.-SAX, D. F.-Brown, J. H. (eds.): Foundations of Biogeography: Classic papers with commentaries. University of Chicago Press, ChicagoLondon. pp. 5-13.

Brown, J. H.-Lomolino, M. V. 1989: Independent Discovery of the Equilibrum Theory of Island Biogeography. - Ecology 70. 6. pp. 1954-1957.

Calarco, M. R. 2020: Animal Studies. The Key Concepts. - Routledge, London-New York. 182 p.

CAMERINI, J. 1993: Evolution, Biogeography and Maps: An Early History of Wallace's Line. - Isis 84. 4. pp. 700-727.

Castree, N. 2011: Nature and Society. - In: Agnew, J.-Livingstone, D. N. (eds.): The SAGE Handbook of Geographical Knowledge. - SAGE, London - Thousand Oaks - New Delhi - Singapore. pp. 287-299.

CAullery, M. 1897: Animaux domestiques et plantes cultivées. - Annales de Géographie 6. 25. pp. 1-13.

Colombino, A. 2020: Animal Geography. A very short introduction. - Geograz 67. pp. 18-20.

DARwIN, C. 1859: On the Origin of Species by Means of Natural Selection. - John Murray, London. 502 p.

DARwin, C. 1868: The Variation of Animals and Plants under Domestication. - John Murray, London. 488 p.

Darwin, C.-Wallace, A. 1858: On the Tendency of Species to form Varieties; and on the Perpetuation of Varieties and Species by Natural Means of Selection. - Journal of the Proceedings of the Linnean Society of London, Zoology 3. 9. pp. 45-62.

Daston, L. 1998: The Nature of Nature in Early Modern Europe. - Configurations. 6. 2. pp. 149-172.

DAviES, J. L. 1961: Aim and method in zoogeography. - Geographical Review 51. 3. pp. 412-417.

Diamond, J. 1997: Guns, Germs and Steel: The Fates of Human Societies. - W. W. Norton, New York. 480 p.

Dudich E. (szerk.) 1942: Az állat és élete. Második rész. - Királyi Magyar Természettudományi Társulat, Budapest. $456 \mathrm{p}$.

Duncan, J. 2009: Berkeley School. - In: Gregory, D.-Johnston, R.-Pratt, G.-Watts, M. J.-Whatmore, S. (eds.): The Dictionary of Human Geography. Wiley-Blackwell, Malden. pp. 45-46. 
Eagle Clarke, W. 1896: Bird migration in the British Isles: its geographical and meteorological aspects. - Scottish Geographical Magazine 12. 12.pp. 616-626.

Ebach, M. C.-Dowding, E. M. 2017: Parochial Pauker and Pioneering Paleobiogeographer. - Zootaxa 4319. 1. pp. 157-168.

EdELMAN, M. 2001: Social movements: changing paradigms and forms of politics. - Annual Review of Anthropology 30. pp. 285-317.

ENDERSEY, J. 2009: Darwin on generation, pangenesis and sexual selection- In: Hodge, J.-RADICK, G. (eds.): The Cambridge companion to Darwin. Cambridge University Press, Cambridge. pp. 73-95.

Engelbrecht, T. H. 1928: Eduard Hahn. - Geographische Zeitschrift 34. 5. pp. 257-259.

Entrikin, J. N.-TePple, J. H. 2006: Humanism and democratic place-making. - In: AitKen, S. -VAlentine, G. (eds.): Approaches to Human Geography. - SAGE, London-Thousand Oaks-New Delhi. pp. 20-29.

EsZENYI O. 2016: A kultúrtáj értelmezésének változása a kultúrföldrajzban. - Földrajzi Közlemények 140. 1. pp. $1-12$.

FoDOR F. 2006: A magyar földrajztudomány története. - Magyar Tudományos Akadémia Földrajztudományi Kutatóintézet, Budapest. 820 p.

GADE, D. W. 1987: Commentary, Frederick J. Simoons, cultural geographer. - Journal of Cultural Geography 7. 2. pp. 135-141.

Germain, L. 1914: Newbigin (Marion I.). Animal Geography. - Annales de Géographie 23-24. 131.pp. $95-96$.

Guppy, H. B. 1893: The distribution of aquatic plants and animals. - Scottish Geographical Magazine 9. 1. pp. $28-33$.

GyURIS F. 2014: Az egyenlőtlen földrajzi fejlődés koncepciója. - Földrajzi Közlemények 138. 4. pp. 293 -305.

GyURIS F. 2020: Variációk egy témára: Hunfalvy, Lóczy és Czirbusz földrajz-felfogásának nemzetközi kapcsolódásai. - Földrajzi Közlemények 144. 4. pp. 396-410.

Hahn, E. 1896: Die Haustiere und ihre Beziehungen zur Wirtschaft des Menschen. - Duncker \& Humblot, Leipzig. $581 \mathrm{p}$.

Hesse, R. 1913: Die ökologischen Grundlagen der Tierverbreitung. - Geographische Zeitschrift 19. 5. pp. 241-259.

HettNeR, A. 1897: Die Haustiere und die menschlichen Wirtschaftsformen. Nach Eduard Hahn. - Geographische Zeitschrift 3. 3. pp. 160-166.

Heymann, M. 2017: 1970s: Turn of an era in the history of science? - Centaurus 59. 1-2. pp. 1-9.

Hines, L. M. 2003: Historical perspectives on the Human-Animal Bond. - American Behavioral Scientist 47. 1. pp. 7-15.

HodgetTs, T.-LoRIMER, J. 2015: Methodologies for animals' geographies: cultures, communication and genomics. - New Methods in Cultural Geography 22. 2. pp. 285-295.

JAHODA, G. 2014: An anthropological history of dehumanization from late-18th to mid-20th centuries. - In: Bain, P. G.-VAes, J.-Leyens, J.-P. (eds.): Humanness and Dehumanization. Routledge, London-New York. pp. 13-33.

KÁDÁR L. 1965: Biogeográfia. A Föld és a földi élet. - Tankönyvkiadó, Budapest. 408 p.

Kersten, E. W. 1982: Sauer and "Geographic Influences". - Yearbook of the Association of Pacific Coast Geographers, Volume 44. University of Hawai'i, Honolulu. pp. 47-73.

Kitchin, R. 2006: Positivistic Geographies and Spatial Science. - In: Aitken, S. - Valentine, G. (eds.): Approaches to Human Geography. - SAGE, London-Thousand Oaks-New Delhi. pp. 20-29.

KowARZIK, R. 1914: Die Verbreitung der Wildschafe.- Petermanns Geographische Mitteilungen 60. pp. 70-72.

Kropotkin, P. 1908: A kölcsönös segítség mint természettörvény. - Athenaeum, Budapest. 230 p.

LARSON, J. 1986: Not without a plan: geography and natural history in the late eighteenth century. - Journal of the History of Biology 19.3. pp. 447-488.

Livingstone, D. 1992: The geographical tradition. - Blackwell, Malden-Oxford-Carlton. 434 p.

Livingstone, D. N. 2011: Environmental Determinism. - In: Agnew, J. A.-Livingstone, D. N. (eds.): The SAGE Handbook of Geographical Knowledge. SAGE, London-Thousand Oaks-New Delhi-Singapore. pp. 368-380.

Mathewson, K. 2011: Sauer's Berkeley School legacy: foundation for an emergent environmental geography. - In: Bocco, G.-Urquijo, P. S.-Vieyra, A. (eds.): Geografía y ambiente en América Latina. Centro de Investigaciones en Geografía Ambiental, Morelia. pp. 51-81.

Morrison, M. L. 2007: Health benefits of Animal-Assisted Interventions. - Complementary Health Practice Review 12. 1. pp. 51-62.

MöвıUS, K. 1894: The geographical distribution and habits of whales. - Geographical Journal 4. 3.pp. 266-268.

NeHring, A. 1892: Die geographische Verbreitung der Säugetiere im östlichen Russland und ihre Bedeutung für die mitteleuropäische diluvial Fauna. - Ausland 65. pp. 727-731, 742-745.

Newbigin, M. I. 1913: Animal Geography. - Clarendon, Oxford. 238 p.

Nobelprize.org 2021: The Nobel Prize in Physiology or Medicine 1973 https://www.nobelprize.org/prizes/medicine/1973/summary/ (Letöltés: 2021.01.07.) 
Nocella II., A. J.-Sorenson, J.-Socha, K.-Matsuoka, A. 2014: Introduction. The emergence of Critical Animal Studies: the rise of intersectional animal liberation. - Counterpoints 448. pp. 19-20xvi.

PALACZKi B. 2016: A Maps of meaning hatása a kulturális földrajzra. - Tér és Társadalom 30. 1. pp. 3-17.

PAPP-VÁRY Á. 2020: Humboldt térképészeti munkássága. - Geodézia és Kartográfia 72. 1. pp. 11-17.

PHILO, C. 1995: Animals, geography and the city: Notes on inclusions and exclusions. - Environment and Planning D: Society and Space 13. 6. pp. 655-681.

PhILO, C. 2017: Theory and methods: Critical essays in Human Geography. - Routledge, Abingdon. 698 p.

Philo, C.-Wilbert, C. (eds.) 2000: Animal Spaces, Beastly Places: New geographies of human-animal relations. Routledge, London. 336 p.

Philo, C.-Wolch, J. (Guest editors) 1998: Society \& Animals 6. 2. 100 p.

PrIEM, F. 1894: La faune australienne. - Annales de Géographie 3. 1. pp. 519-522.

PROBÁLD, F. 1995: A regionális földrajz helye a geográfiában. Háttérvázlat - In: NemEs NAGY J. (szerk.): Földrajz, regionális tudomány: tudományelméleti tanulmányok. ELTE TTK Regionális Földrajzi Tanszék, Budapest. pp. 35-62.

RADICK, G. 2009: Is the theory of natural selection independent of its history? - In: HodGE, J.-RADICK, G. (eds.): The Cambridge companion to Darwin. Cambridge University Press, Cambridge. pp. 147-172.

RECLus, É. 1901: On Vegetarianism. - In: Humane Review. https://theanarchistlibrary.org/library/elisee-reclus-on-vegetarianism (Letöltés: 2021.03.19.)

Regan, T. 1983: The Case for Animal Rights. - University of California, Berkeley. 425 p.

Robinson, G. M. 2018: Agricultural geography. - In: Richardson, D.-CASTree, N.-Goodchild, M. F.-Kobayashi, A.-LiU, W.-Marston, R. A. (eds.): The International Encyclopedia of Geography. WileyBlackwell, Chicester-New York pp. 1-15.

RodRigue, C. M. 1992: Can religion account for early domestication? - Professional Geographer 44. 4. pp. 417-430.

Rootes, C. 2004: Environmental Movements. - In: Snow, D. A.-Soule, S. A.-Kriesi, H. (eds.): The Blackwell Companion to Social Movements. Blackwell, Malden-Oxford-Carlton. pp. 608-640.

Rowan, A. N. 1987: Editorial. - Anthrozoös 1. 1. pp. 1.

Ruthven, A. G. 1912: The local distribution of the reptile-amphibian fauna in Southern Vera Cruz and its bearing on the origin of the savannahs. - Annals of the American Association of Geographers 2. 1. pp. 41-48.

SAUER, C. O. 1952: Agricultural origins and dispersals. - The American Geographical Society, New York. 110 p.

SCLATER, W.L. 1894: The geography of mammals. No. I. Introductory. - Geographical Journal 3. 2. pp. 95-105.

Shapiro, K.-DeMello, M. 2010: The state of Human-Animal Studies. - Society \& Animals 18.3.pp.307-318.

Sharp, J. 2009: Humanistic geography. - In: Gregory, D. - Johnston, R.-PratT, G. - WATts, M. J.-Whatmore, S. (eds.): The Dictionary of Human Geography. Wiley-Blackwell, Malden. pp. 356-358.

Shaw, D. J. B.-OldFiELD, J. D. 2007: Landscape Science: A Russian Geographical Tradition. - Annals of the Association of American Geographers 97. 1. pp. 111-126.

ShELFORD, V. E: 1913: The significance of evaporation in Animal Geography. - Annals of the American Association of Geographers 3. 1. pp. 29-41.

Shennan, S.-Clout, H. 2017: David Russel Harris (1930-2013). - Bibliographical Memoirs of Fellows of the British Academy 16. pp. 363-385.

SHERMER, M. 2002: In Darwin's Shadow: The Life and Science of Alfred Russel Wallace. - Oxford University Press, New York. 448 p.

Singer P. 1975: Animal Liberation. - New York Review, New York. 301 p.

Smith, C. H. 2010: Alfred Russel Wallace, Geographer. - Geography Compass 4. 5. pp. 388-401.

SzÉKy P. 1989: A Föld állatvilága. Kis állatföldrajz. - Mezőgazdasági Kiadó, Budapest. 184 p.

TEleKi P. 1917: A földrajzi gondolat története. - A szerző kiadása, Budapest. 193 p.

TomKA, B. 2009: Európa társadalomtörténete a 20. században. - Osiris Kiadó, Budapest. 646 p.

Trachsel, M. 2017: Domestication. - In: Urbanik, J.-Johnston, C. L. (eds.): Humans and animals. A geography of coexistence. - ABC-CLIO, Santa Barbara. pp. 108-110.

TuAn, Y.-F. 1984: Dominance and affection: The making of pets. - Yale University Press, New Haven. 193 p.

UDVARDY M. 1983: Dinamikus állatföldrajz. - Tankönyvkiadó, Budapest. 496 p.

Urbanik, J. 2012: Placing animals. An Introduction to the Geography of Human-Animal Relations. Rowman \& Littlefield, Lanham. 206 p.

VARGA Z. 2018: Állatvilág. - In: Kocsis K. (fószerk.): Magyarország nemzeti atlasza 2. kötet. Természeti környezet. Magyar Tudományos Akadémia, Csillagászati és Földtudományi Kutatóközpont, Budapest.pp. 104-111.

Vigne, J.-D. 2011: The origins of animal domestication and husbandry: A major change in the history of humanity and the biosphere. - Comptes Rendus Biologies 334. 3. pp. 171-181.

Viles, H. 2005: A Divided Discipline? - In: Castree, N.-Rogers A.-Sherman, D. (eds.): Questioning Geography: Fundamental Debates. Blackwell, Malden-Oxford-Carlton. pp. 26-38.

WÉBER M. 1973: Az állatföldrajz alapjai. - Tankönyvkiadó, Budapest. 106 p. 
West, R. C. (ed.) 1990: Pioneers of Modern Geography: Translations Pertaining to German Geographers of the Late Nineteenth and Early Twentieth Centuries. - Department of Geography \& Anthropology, Louisiana State University, Baton Rouge. Geoscience and Man, Volume 28. 188 p.

Wilson, R. M. 2013: Environmental Histories. - In: Johnson, N. C.-Schein, R. H.-Winders, J. (eds.): The Wiley-Blackwell Companion to Cultural Geography. Wiley-Blackwell, Chichester. pp. 355-370.

White, R. J. 2015: Animal geographies, anarchist praxis, and critical animal studies. - In: GILLESPIE, K. - COLLARD, R.-C. (eds.): Critical Animal Geographies. Routledge, Abingdon-New York. pp. 19-35.

WolCH, J.-EMEL, J. (Guest editors) 1995: Bringing the animals back in. Environment and Planning D: Society and Space 13. 6. 154 p.

Wolch, J.-Emel, J.-Wilbert, C. 2003: Reanimating cultural geography. - In: Anderson, K.-Domosh M.-Pile, S.-Thrift, N. (eds.): Handbook of cultural geography. - SAGE, London-Thousand Oaks-New Delhi. pp. 184-206.

WSU 2021: Dr. Bustad, founder of PPP.

- https://www.vetmed.wsu.edu/About-the-college/history/deans/Leo-Bustad (Letöltés: 2021.01.08.)

Online gyújtemény

Persée (Annales de Géographie folyóirat bibliográfiai számai): https://www.persee.fr/collection/geo 